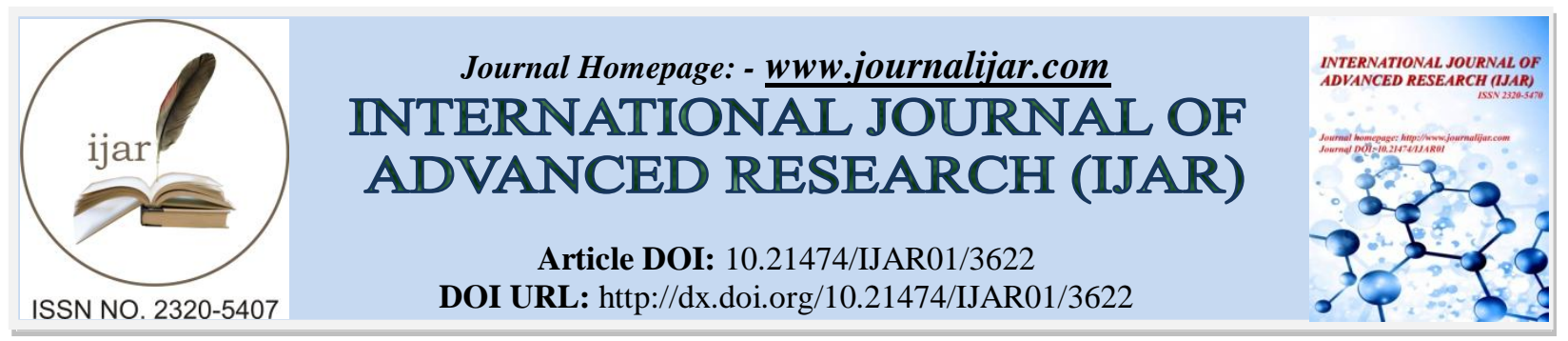

RESEARCH ARTICLE

\title{
ACTIVITY OF ASPARAGINASE, PURIFIED AND CHARACTERIZED FROM FROZEN SEEDS OF PISUM SATIVUM.
}

\author{
Zena Abdullah Khalaf ${ }^{1}$, Ayat Adnan Abbas, ${ }^{2,}$ and Ali Mosa Rashid Al-Yasari ${ }^{3}$. \\ 1. Ministry of Environment/ Republic of Iraq. \\ 2. Biotechnology Research Center, Al - Nahrain University, Baghdad, Iraq. \\ 3. College of Veterinary Medicine, Al-Muthanna University, Samawa City, Al-Muthanna Province, Iraq.
}

\section{Manuscript Info}

Manuscript History

Received: 07 January 2017

Final Accepted: 05 February 2017

Published: March 2017

Key words:-

L-asparaginase; Pisum sativum; Enzyme purification

\begin{abstract}
Asparaginase was extracted from Frozen Plant seeds of Pisam sativum collected from a field crop after 3 months of freezing. Enzyme specific activity was $(74.1 \mathrm{U} / \mathrm{mg})$. Asparaginase was extracted from frozen seeds and purified by ion exchange chromatography using DEAECellulose and gel filtration chromatography using sephadex G-200. We found that the molecular weight of asparaginase is 44000 Dalton, specific activity of Purified asparaginase was $226.5 \mathrm{U} / \mathrm{mg}$. Purified asparaginase was characterized, the optimum $\mathrm{pH}$ for enzyme activity and stability was $\mathrm{pH} 8.5$ and 9.5 respectively, while the optimum temperature for enzyme activity and stability was $40{ }^{\circ} \mathrm{C}$ and $37^{\circ} \mathrm{C}$ respectively.
\end{abstract}

Copy Right, IJAR, 2017,. All rights reserved.

\section{Introduction:-}

L-asparaginase (E.C.3.5.1.1) is the enzyme that catalyzesthe hydrolysis of the amide group of L-asparagine releasing L-aspartate and ammonia. The enzyme plays important roles in the metabolism of all living organisms and the pharmacology as well (1). Asparagine is predominates in the transport of nitrogen in many legumes studied so far and constitutes an important source of reduced nitrogen for developing seeds (2).

Pea (Pisum sativum) is a member of Leguminecea family that is widely grown in the world as a source of protein for human food (3). Green pea can be eaten as a cooked vegetable, or can be marketed fresh, canned, or frozen while ripe dried pea is used whole, split, or made into flour (4). Pea is reported to have potential antioxidant, antiinflammatory and antimicrobial effect $(5 ; 6)$.

The plant asparaginase from frozen Pisum sativum has been less studied. In plants, L-asparagine is the major nitrogen storage and transport compound (2). According to importance of L-asparaginase in different therapeutical treatment. Hence the necessity to find out a novel sources of this enzyme from plants this study was aimed to extract, purify and characterize the enzyme from frozen plant seeds of Pisum sativum in order to determine the activity of asparaginase from frozen sources of plant which could be considered as a unique case study 


\section{Materials and Methods:-}

Sample collection:-

Plant seeds of Pisum sativum were collected during first season of 2016 from field of plant crops and freezed for (3) months at $0{ }^{\circ} \mathrm{C}$. (7) 1

\section{Extraction of asparaginase from frozen plant seeds:-}

Extraction of asparaginase from frozen plant seeds was achieved according to Chang and Farnden (8) by homogenization, 10 grams of frozen plant seeds with three volumes of $0.05 \mathrm{M}$ potassium phosphate buffer, $\mathrm{pH} 8.0$ containing $1.5 \mathrm{M}$ sodium chloride, 1mM PMSF, 1mM EDTA, and 10\% (w/v) glycerol, then centrifuged at 10000 rpm for 20 minutes. Supernatant was regarded as crude enzyme.

\section{Enzyme assay:-}

Asparaginase was assayed according to Nesslerization method based on the conversion of L-asparagine to Ammonia and L-asparatate, as described by Ren et al. 2010 (9).

Protein concentration in plant extracts and enzyme concentrates was determined according to Bradford method (10).

\section{Purification of asparaginase:-}

Asparaginase from frozen seeds of Pisum sativum was purified by ion exchange chromatography using DEAECellulose $(2 \times 23 \mathrm{~cm})$ equilibrated with $50 \mathrm{mM}$ potassium phosphate buffer $(\mathrm{pH} 8.0)$, then bound proteins were eluted with a flow rate of $3 \mathrm{ml} /$ fraction by gradient concentrations of $\mathrm{NaCl}(0.1-0.5 \mathrm{M})$ in $0.05 \mathrm{M}$ potassium phosphate buffer solution ( $\mathrm{pH}$ 8.0). Fractions represent asparaginase activity were collected, concentrated and applied onto gel filtration chromatography column using Sephadex G-200 $(1.6 \times 43 \mathrm{~cm})$, and eluted with $0.1 \mathrm{M}$ potassium phosphate buffer (pH8.0) with flow rate of $20 \mathrm{ml} /$ hour. Fractions represent asparaginase activity were pooled, concentrated and kept at $4^{\circ} \mathrm{C}$ for further analysis.

\section{Characterization of purified asparaginase:-}

Characterization of purified asparaginase was achieved by determining the optimum $\mathrm{pH}$ and temperature for enzyme activity and stability, and the activation energy according to Segel (11), while the molecular weight of asparaginase was determined by gel filtration chromatography technique using Sephadex G-200 as described by Andrews (12).

\section{Result and Discussion:-}

Asparaginase activities were detected in plant seeds of Pisum sativum that was frozen for three months to determine the activity of enzyme. Al-Hussaini, (2012), showed that the quality of beans and peas increased after three months freezing, in spite of the content of vitamin $\mathrm{C}$ was decreased during freezing periods of 3 months (7).

Results indicated in Table (1) showed that asparaginase activity $(571.0 \mathrm{U} / \mathrm{ml})$, specific activity of $(74.1 \mathrm{U} / \mathrm{mg})$ and total activity $(5710 \mathrm{U})$ were noticed in frozen plant seeds extract. According to these results frozen plant seeds were used for enzyme production, purification, characterization of asparaginase to determine the activity of the Frozen plant sources. Khalaf, et al., (2012), showed that asparaginase activity that extracted from fresh seeds of Pisum sativum var. Jof were (605.0 U) and specific activity (75.6 U/mg), (13).

Table 1:- Asparaginase activity and specific activity in the extracts of frozen plant seeds of Pisum sativum.

\begin{tabular}{|c|c|c|c|c|c|}
\hline Plant part & $\begin{array}{c}\text { Volume } \\
(\mathrm{ml})\end{array}$ & $\begin{array}{c}\text { Activity } \\
(\mathrm{U} / \mathrm{ml})\end{array}$ & $\begin{array}{c}\text { Protein } \\
(\mathrm{mg} / \mathrm{ml})\end{array}$ & $\begin{array}{c}\text { Specific Activity } \\
(\mathrm{U} / \mathrm{mg})\end{array}$ & $\begin{array}{c}\text { Total activity } \\
(\mathrm{U})\end{array}$ \\
\hline Seeds & 10 & 571.0 & 7.7 & 74.1 & 5710 \\
\hline
\end{tabular}

Asparaginase extracted from frozen seeds of Pisum sativum was purified by ion-exchange chromatography using DEAE-Cellulose. Results indicated in figure (1) showed that one protein peak appeared in the washing step, while there are three protein peaks were appeared after elution peak as mentioned with gradient concentrations of sodium chloride, asparaginase activity was detected in the third peak in figure (1). The maximum asparaginase activity and specific activity in the asparaginase concentrate were $483.0 \mathrm{U} / \mathrm{ml}$ and $155.8 \mathrm{U} / \mathrm{mg}$ respectively, with $2.06 \%$ fold of purification in the table (2). 
Gel filtration chromatography technique was the next step for purification of asparaginase after the ion-exchange chromatography step. Results mentioned in figure (2) showed that only one protein peak represents asparaginase activity was appeared after elution with $0.1 \mathrm{M}$ potassium phosphate buffer solution.

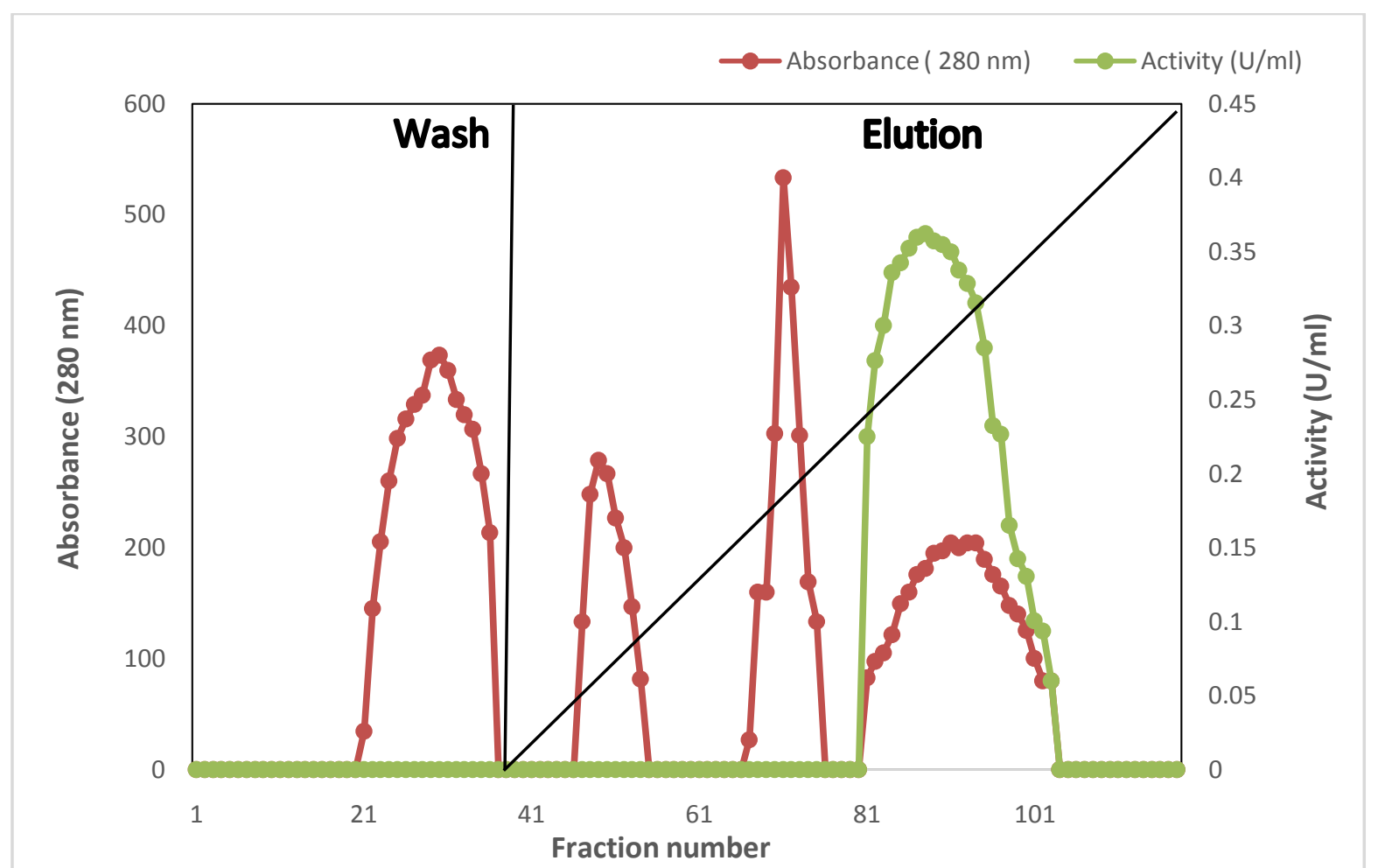

Figure 1:- Ion exchange chromatography for purification of asparaginase from frozen seeds of Pisum sativum using DEAE-Cellulose column $(2 \times 23 \mathrm{~cm})$ with a flow rate of $20 \mathrm{ml} / \mathrm{hour}$. 


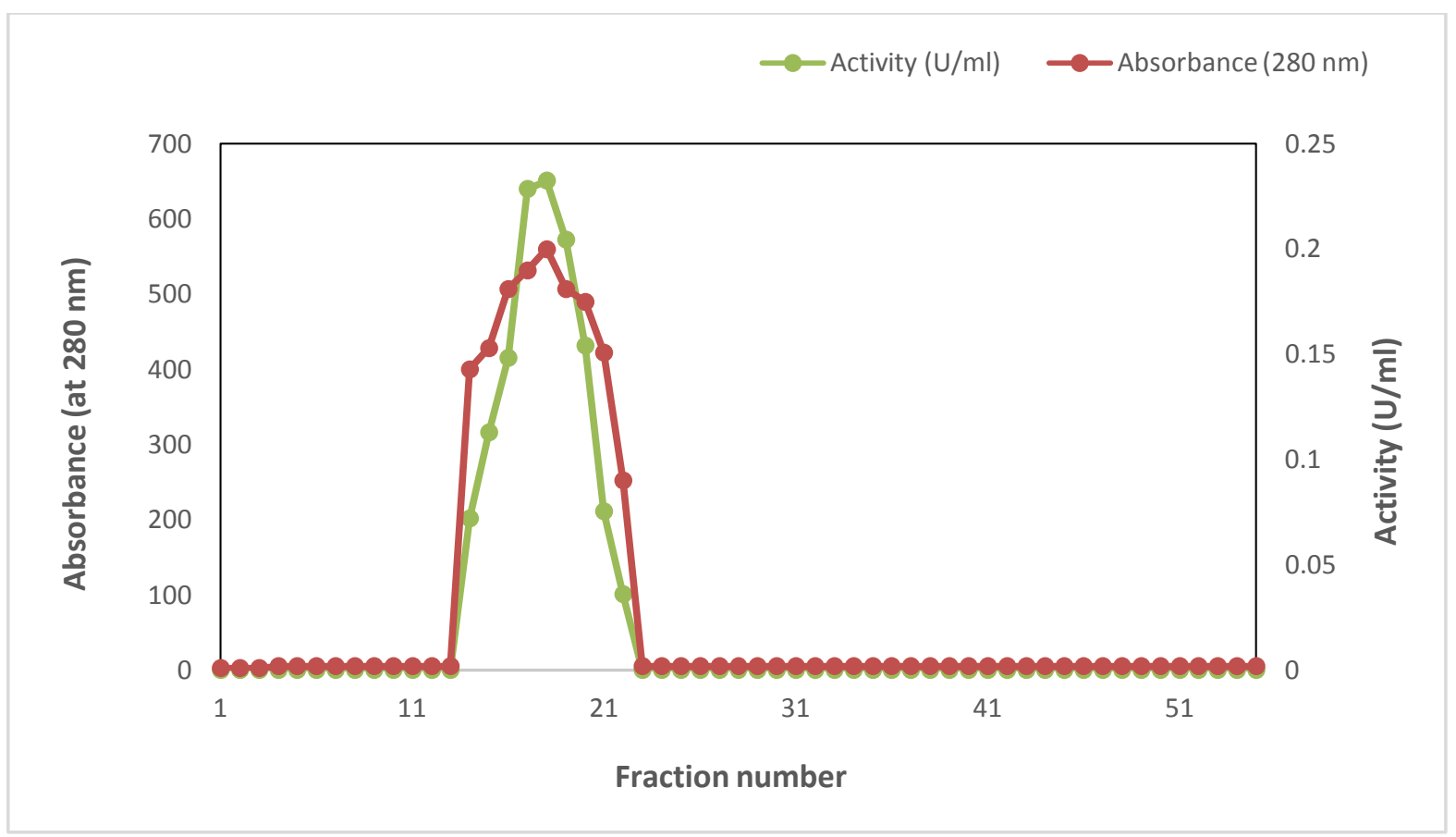

Figure 2:- Gel filtration chromatography for purification of asparaginase from frozen seeds of Pisum sativum using Sephadex G-200 (1.6×43 cm) equilibrated with potassium phosphate $(\mathrm{pH} 8.0)$, fraction volume was $5 \mathrm{ml}$ at flow rate of $20 \mathrm{ml} /$ hour.

Results indicated in table (2) showed that there is an increase in both activity and specific activity of the purified enzyme with a purification fold of 0.013 and an increase in the yield of asparaginase to $3.05 \%$.

In other study, it was found that purification of asparaginase from fresh seeds of Pisum sativum using Sephadex G200 as a second step (after DEAE-Cellulose Ion Exchange cromatography) gives the highest specific activity of $226.5 \mathrm{U} / \mathrm{mg}$ and 0.013 fold of purification with $3.05 \%$ yield, (14).

Table 2:- Purification steps of asparaginase extracted from frozen seeds of Pisum sativum.

\begin{tabular}{|c|c|c|c|c|c|c|c|}
\hline Step & $\begin{array}{c}\text { Volume } \\
(\mathrm{ml})\end{array}$ & $\begin{array}{c}\text { Activity } \\
(\mathrm{U} \backslash \mathrm{ml})\end{array}$ & $\begin{array}{c}\text { Protein } \\
\text { conc. } \\
(\mathrm{mg} \backslash \mathrm{ml})\end{array}$ & $\begin{array}{c}\text { Specific } \\
\text { activity } \\
\text { (U\mg) }\end{array}$ & $\begin{array}{c}\text { Total } \\
\text { activity } \\
\text { (U) }\end{array}$ & Purification fold & $\begin{array}{c}\text { Yield } \\
(\%)\end{array}$ \\
\hline $\begin{array}{c}\text { Crude } \\
\text { enzyme }\end{array}$ & 100 & 571.0 & 7.7 & 74.1 & 250098 & 1 & 1 \\
\hline $\begin{array}{c}\text { Ion } \\
\text { exchange }\end{array}$ & 15 & 483.0 & 3.0 & 155.8 & 15939 & 2.06 & 0.06 \\
\hline $\begin{array}{c}\text { Gel } \\
\text { filtration }\end{array}$ & 5 & 650.9 & 2.9 & 226.5 & 3284.5 & 0.013 & 3.05 \\
\hline
\end{tabular}

Molecular weight of the purified asparaginase was determined by gel filtration using Sephadex G-200 in the presence of six standard proteins. Results indicated in figure (3) showed that asparaginase has a molecular weight of 44000 Dalton. Molecular weight of asparaginase differs according to the type of the produced genera, species, type of storage, and parts of plant. There was no evidence for dissociation into subunits on SDS-PAGE, and this suggests that asparaginase is a monomeric protein of molecular weight $69000 \mathrm{Da}(\mathbf{1 5}, \mathbf{1 6})$. 


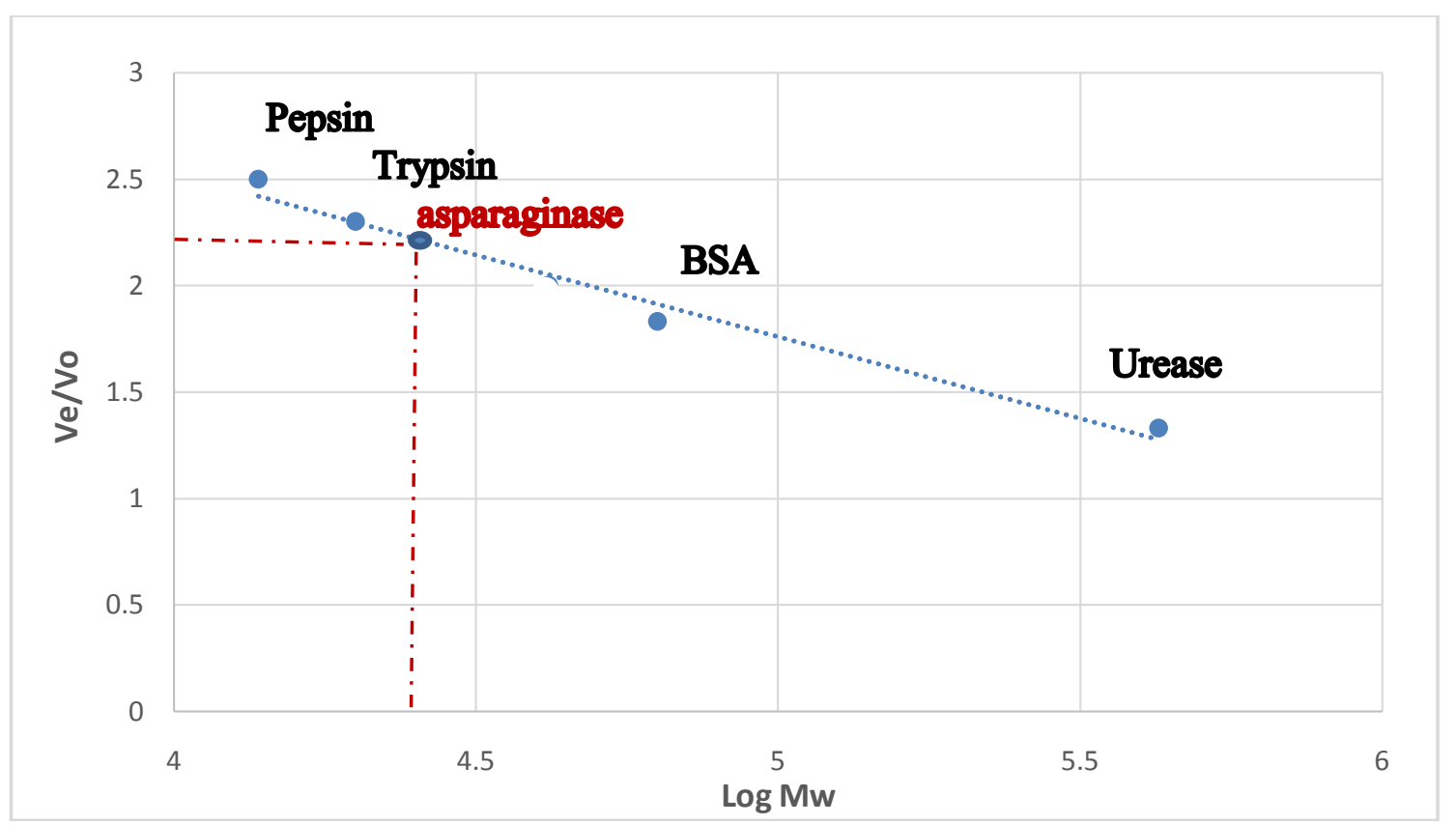

Figure 3:- Selectivity curve for determining the molecular weight of purified asparaginase extracted from Pisum sativum seeds by gel filtration chromatography using Sephadex G-200 $(1.6 \times 43 \mathrm{~cm})$.

Optimum $\mathrm{pH}$ for activity of purified asparaginase from frozen seeds of Pisum sativum was determined by incubation with asparagine at different $\mathrm{pH}$ values ranging between $\mathrm{pH} 4$ and $\mathrm{pH} 10.5$. Results indicated in figure (4) showed that asparaginase was a maximum activity of $155.4 \mathrm{U} / \mathrm{ml}$ at $\mathrm{pH} 10.0$. Effect of $\mathrm{pH}$ on the rate of hydrolysis of asparagine is due to the effect of asparaginase on the velocity of enzyme-substrate complex formation and breakdown in addition to its effect on the ionic state of the active site of enzyme since the change in the hydrogen ion concentration may affect the ionization state of amino acid side chains in the enzyme active site $(\mathbf{1 7}, \mathbf{1 8})$.

On the other hand, results indicated in figure (5) showed that asparaginase was more stable at $\mathrm{pH}$ values ranged between 8.5 and 9.5, at this range enzyme gain both maximum activity and remaining activity, while the activity and remaining activity was lower when the enzyme was incubated at $\mathrm{pH}$ values less or more than optimum.

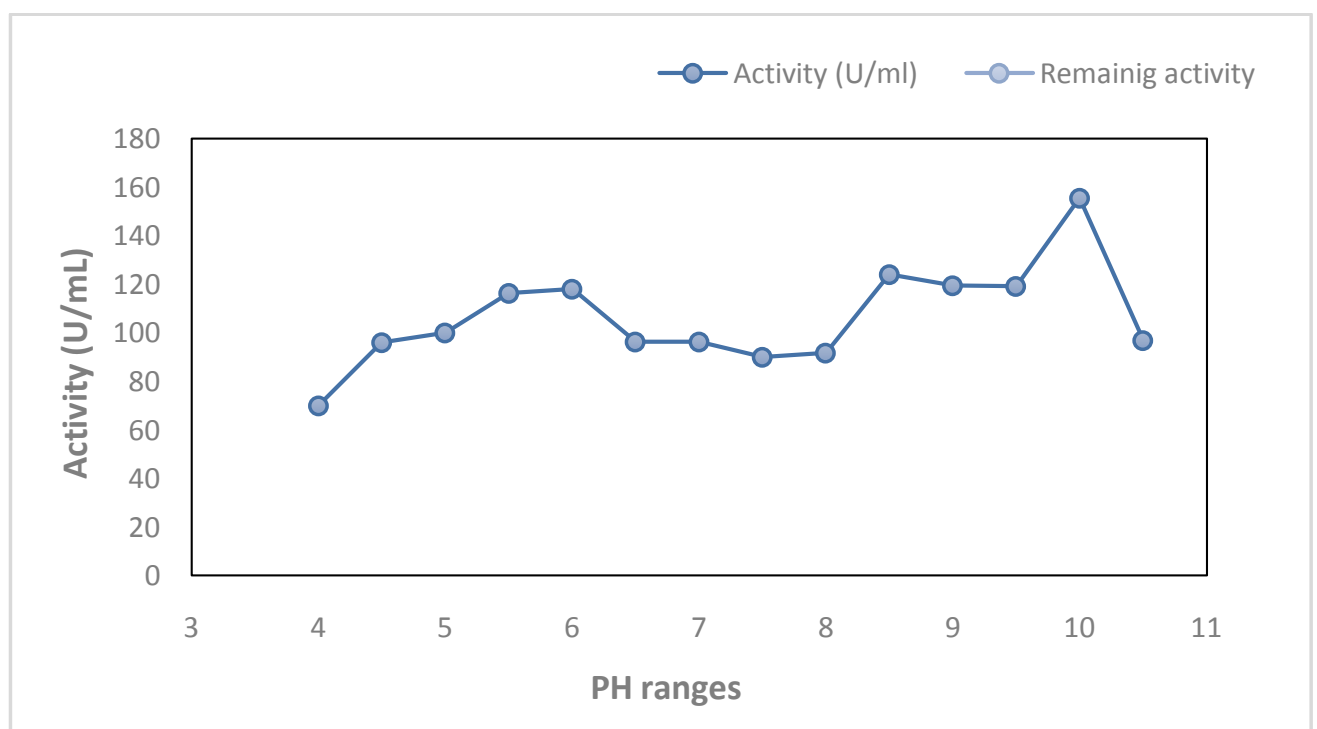

Figure 4:- Effect of $\mathrm{pH}$ on activity of purified asparaginase extracted from frozen seeds of Pisum sativum. 


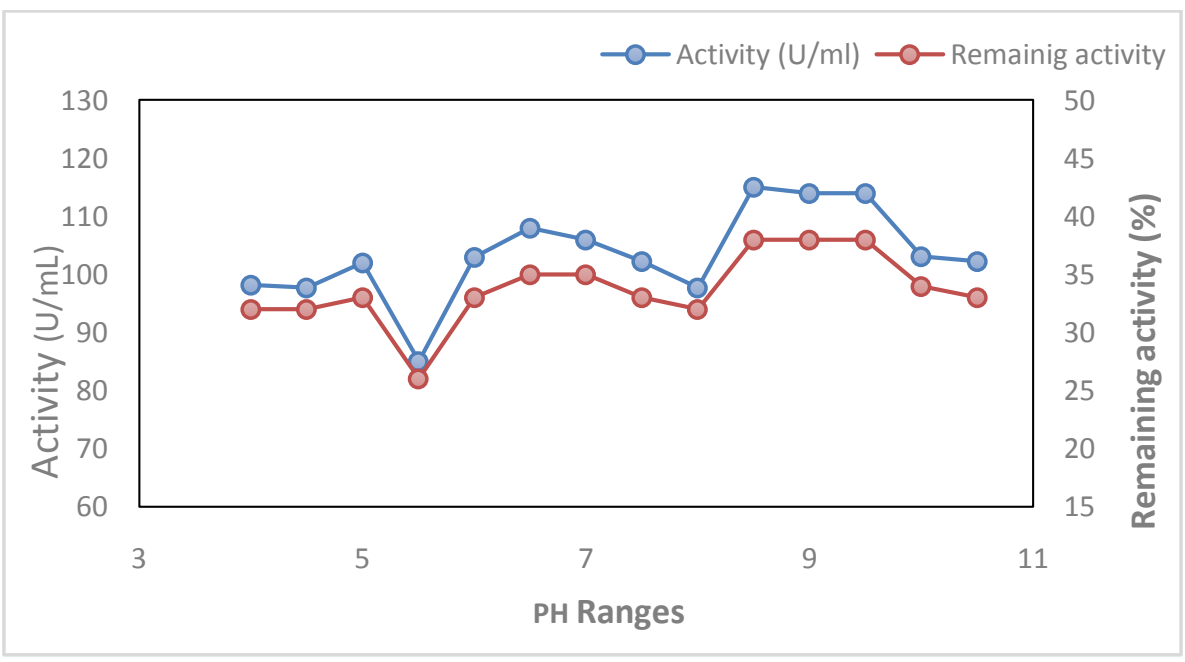

Figure 5:- Effect of $\mathrm{pH}$ on stability of purified asparaginase extracted from Frozen seeds of Pisum sativum

Saleh et al., (2015) found that asparaginase from Phaseolus vulgaris seeds had optimum $\mathrm{pH}$ at 8.0. It showed that the tertrameric form of asparaginase from Phaseolus vulgaris seeds remain stable at $\mathrm{pH}$ values ranged between $\mathrm{pH}$ 7.5-9.0, it had high stability at alkaline $\mathrm{pH}$ when incubated for up to $24 \mathrm{~h}(19)$.

Effect of temperature on the purified asparaginase was also studied. Results indicated in figure (6) showed that the optimum temperature for enzyme activity was $524.6 \mathrm{U} / \mathrm{ml}$ at $40^{\circ} \mathrm{C}$, while the activity was decreased at less or higher than this temperature. Most enzyme reactions were found to be accelerated with the increase in temperature for a limited range.

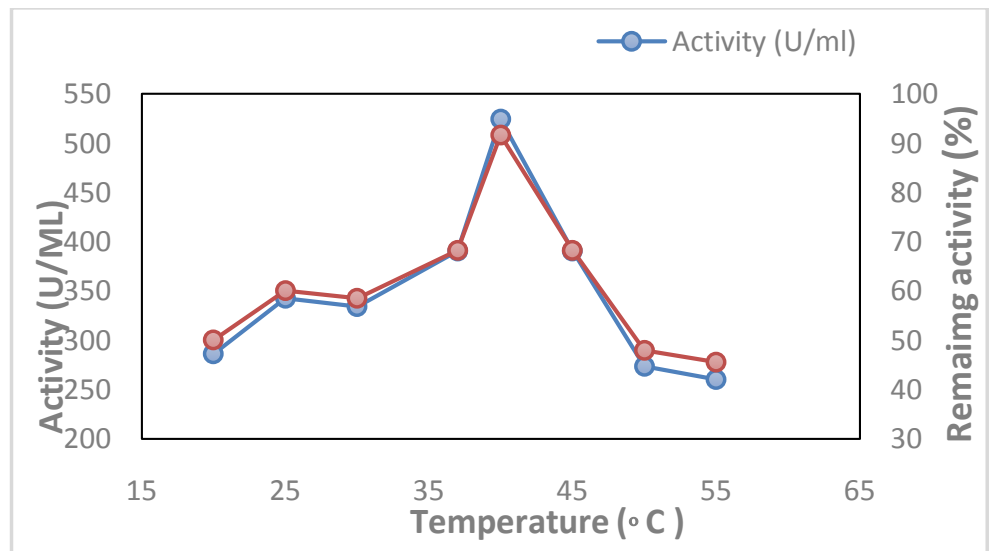

Figure 6:- Effect of temperature on the activity of purified asparaginase extracted from frozen seeds of Pisum sativum.

It was also found that the asparaginase stability was $624 \mathrm{U} / \mathrm{ml}$ at at $37^{\circ} \mathrm{C}$ as shown in figure (7), at this temperature enzyme gain maximum activity and remaining activity, while they were decreased when the enzyme was incubated at temperatures less or more than the optimum temperature. The increase in temperature may lead to denaturation of enzyme by destruction the three dimensional structure of protein which leads to inactivation of the enzyme at higher temperatures. 


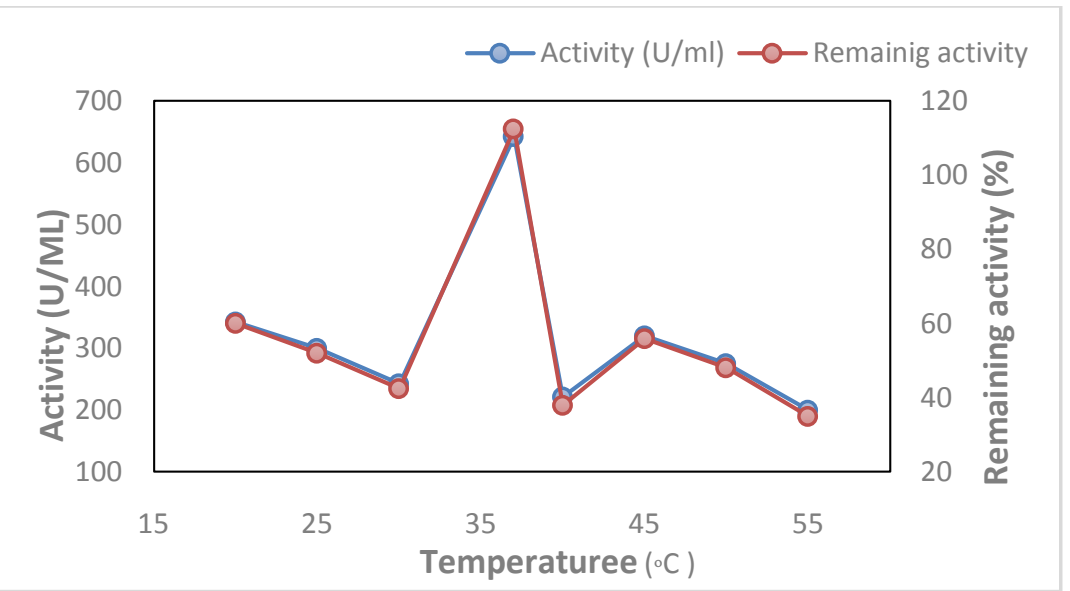

Figure 7:- Effect of temperature on stability of asparaginase purified from seeds of Pisum sativum.

\section{Reference:-}

1. Borek, D. and Jaskolski, M. (2001). Sequence analysis of enzymes with asparaginase activity. Acta Biochem. Polon. J., 48:893-902.

2. Sieciechowicz, K. A.; Joy, K. W. and Irleland, R. J. (1988). The Metabolism of Asparaginase in Plants. Phytochem. J., 27(3):633-671.

3. Faostat (2008). Available at http://www.fao.org Fernandez-Aparicio M., Perez-De-Luque A., Prats E., Rubiales D. (2008a): Variability of interactions between barrel medic (Medicago truncatula) genotypes and Orobanche species. Annals Applied Biology, 153: 117-126.

4. Davies, D. R., Berry, G. J. Heath, M. C. and Dawkins. T. C. K. (1985). Pea (Pisum sativum L.). In: R.J. Summer field and EH Roberts, (eds.), Williams Collins Sons and Co. Ltd, London, UK. 147-198.

5. Ho, C.Y., Y.T. Lin, R.G. Labbe and K. Shetty. 2003. Antimicrobial activity of sprouted pea and chickpea extracts against Helicobacter pylori. http://ift.confex.com/ift/ 2003/techprogram/paper_17775.htm.

6. Amarowicz, R., Karamac, M. and Weider, S. (2001). Antioxidant activity of phenolic fraction of pea (Pisum sativum). Czech. J. Food Sci. 19(4): 139-142.

7. Al-Hussaini, K. S, 2012. Effect of blanching and packages in content vitamin C in green beans and green peas frozen for different Periods. Al-kofaa Journal for agricultural sciences. 4(1): 23-30.

8. Chang, K. S. and Farnden, K. J. (1981). Purification and Properties of asparaginase from Lupinus arboreus and Lupinus angustifolius. Arch. Biochem. Biophys. J., 208:49-58.

9. Ren, J.; He. F. and Zhang, L. (2010). The construction and application of a new PPY-MSPQC for L-asparaginase activity assay. Sensors and Actuators. J., 145: 272-277.

10. Bradford, M. M. (1976). A rapid and sensitive method for the quantitation of microgram quantities of protein utilizing the principle of protein-dye binding. Anal. Biochem. J., 72:248-254.

11. Segel, E. H. (1976). Biochemical Calculation. 2th edition. John Wiley and sons. New York.

12. Andrews, P. (1970). Estimation of molecular size and molecular weights of biological compounds by gel filtration. Methods of Biochem. Anal., 18:1-53.

13. Khalaf, Z. A., Al-Ani, N. K., and Jasim, H. M. (2012). Optimum conditions for asparaginase extraction from Pisum sativum subspp Jof,. Iran Journal of Plant Physiology, vol. 2,: 517-521.

14. Khalaf, Z. A., (2012). Production, purification and characterization of asparaginase from Pisum sativum var.Jof. MS.c. thesis, Collage of science, Al-Nahrain University. Iraq.

15. Sodek, L.; Lea, P. J. and Miflin, B. J. (1980). Distribution and Properties of a potassium-dependent asparaginase isolated from developing seeds of Pisum sativum and other plants. Plant Physiol. J., 65: 22-26.

16. Chagaz, E. P. and Sodek, L. (2001). Purification and Properties of asparaginase from the testa of immature seeds of pea (Pisum sativum L.) Int. J. Braz. Arch. of Biol. and Technol. 239-244.

17. Mckee, J. R. and Mckee, T. (1996). Biochemistry: the molecular Basis of life. (3rd edition). Mcgraw Hill. P:121.

18. Bezkorovainy, A. and Rafelson, M. F., (2007). Concise Biochemistry. Marcel Dekker, Inc. New York. Pp:108-111.

19. Saleh A. Mohamed, Mohamed F. Elshal, Taha A. Kumosani, and AliaM. Aldahlawi, (2015). Purification and Characterization of Asparaginase from Phaseolus vulgaris Seeds. Hindawi Publishing Corporation. Evidence-Based Complementary and Alternative Medicine. Volume 2015, Article ID 309214,:6-13 